\title{
Analisis Usability Menggunakan Metode USE Questionnaire Pada Website Ciputra Enterprise System
}

\author{
Yulmy Satria Mandala Putra ${ }^{1^{*}}$, Rinabi Tanamal ${ }^{2}$ \\ ${ }^{1,2}$ Program Studi Teknik Informatika, Universitas Ciputra Surabaya, Jawa Timur \\ Email: ${ }^{1 *}$ yulmysatria85@gmail.com, ${ }^{2}$ r.tanamal@ ciputra.ac.id
}

(Naskah masuk: 7 Apr 2020, direvisi: 26 Mei 2020, diterima: 29 Mei 2020)

\begin{abstract}
Abstrak
Dengan berkembangnya teknologi informasi menyebabkan efektivitas dalam bekerja meningkat. Dengan adanya website CES (Ciputra Enterprise System) membuat pekerjaan atau tugas kantor dapat dikerjakan di mana saja dan kapan saja. Website yang baik adalah yang bisa meningkatkan keefektifan ketika digunakan dan membuat penggunaan website lebih mudah. Website CES (Ciputra Enterprise System) merupakan sistem baru yang dibuat oleh Ciputra. Namun karena website ini masih baru sehingga masih banyak kekurangan yang dimiliki dari segi kemudahan yang dirasakan pengguna dan efisiensi melalui pengalaman pengguna. Oleh karena itu, penelitian ini bertujuan untuk menganalisis usability dari website CES (Ciputra Enterprise System) untuk meningkatkan usability sistem dengan menggunakan metode USE Questionnaire. Metode ini terdiri dari 4 parameter yaitu Usefulness, Ease of Use, Ease of Learning dan User Satisfaction. Hasil dari penelitian menunjukkan bahwa variabel dari USE Questionnaire yaitu Usefulness, Ease of Use, Ease of Learning berpengaruh signifikan terhadap User Satisfaction secara simultan. Secara parsial, variabel Usefulness, Ease of Use, Ease of Learning berpengaruh signifikan terhadap User Satisfaction. Faktor dominan yang mempengaruhi User Satisfaction (Kepuasan User) dalam menggunakan website CES (Ciputra Enterprise System) adalah Ease of Learning (Kemudahan belajar) dengan nilai koefisien 0,390.
\end{abstract}

Kata Kunci: Website, Usability, Usefulness, Ease of Use, Ease of Learning, User Satisfaction, Use Questionnaire.

\section{Usability Analysis Using USE Questionnaire Method on Ciputra Enterprise System Website}

\begin{abstract}
With the development of information technology, it enhances the effective way of working. Website of CES (Ciputra Enterprise System) makes office works or tasks can be done anywhere and anytime. A good website can increase the effectiveness of its use and easier to use. Website of CES (Ciputra Enterprise System), which is a new system made by Ciputra, still has a lot of flaws in terms of user convenience and efficiency through the user experiences. Therefore, this research aims to analyze the usability of CES (Ciputra Enterprise System) website to improve the usability of a system using USE Questionnaire method. This method comprises 4 parameters namely Usefulness, Ease of Use, Ease of Learning and User Satisfaction. The results of the study showed that the variables from USE Questionnaire namely Usefulness, Ease of Use, Ease of Learning were significantly affected by User Satisfaction simultaneously. Partially, the Usefulness, Ease of Use, Ease of Learning variables has significant effect on User Satisfaction. The dominant factor that affects User Satisfaction in using CES (Ciputra Enterprise System) website is the Ease of Learning with a coefficient value of 0.390.
\end{abstract}

Keywords: Website, Usability, Usefulness, Ease of Use, Ease of Learning, User Satisfaction, USE Questionnaire. 


\section{PENDAHULUAN}

A. Latar Belakang

Kemajuan dalam bidang teknologi yang sangat pesat juga sangat membantu kegiatan manusia sehari-hari dalam bekerja agar pekerjaan apapun menjadi lebih efektif. Dengan adanya sistem informasi pada sebuah instansi atau lembaga dapat memudahkan orang dalam mengerjakan tugas apapun.

Di Indonesia banyak sekali sistem informasi yang sudah dibuat oleh masing-masing lembaga atau instansi untuk memudahkan pekerjaan mereka masing-masing. Namun kebanyakan lembaga atau instansi kurang memperhatikan apakah sistem informasi yang dibuat sudah mudah digunakan dan sesuai dengan yang diharapkan.

Ciputra adalah salah satu perusahaan besar yang berjalan dibidang properti yang juga mengikuti perkembangan teknologi. Perusahaan ini membuat sistem informasi yaitu website Ciputra Enterprise System (CES). Website CES adalah sebuah sistem yang digunakan oleh semua karyawan untuk bekerja dan menyelesaikan tugasnya, dengan harapan membantu meningkatkan performa karyawan Ciputra.

Website CES ini sudah mulai diakses hampir di seluruh grup Ciputra. Website CES masih baru dikembangkan sehingga memungkinkan masih banyak kekurangan yang dimiliki dari segi kemudahan penggunaan dan efisiensi melalui pengalaman pengguna.

Dalam membangun sistem yang baik, salah satu bagian yang penting adalah segi kegunaan. Usability dekat hubungannya dengan user experience. User experience sangat penting dalam membangun sebuah sistem, terlebih lagi dalam sistem website CES. Dari user experience kita dapat melihat kemudahan dan efisiensi yang dirasakan melalui pengalaman pengguna dalam menggunakan sistem ini.

Pengukuran terhadap keberhasilan suatu implementasi sistem dilakukan untuk mengetahui sejauh mana kemampuan dari pengguna saat menggunakan sistem tersebut hingga tercapai tujuan dari pembuatan sistem itu sendiri. Kondisi ini mendorong dilakukannya penelitian ini dengan tujuan melihat sejauh mana usability sistem dari website CES yang digunakan grup Ciputra. Tujuan ini akan dicapai dengan menggunakan USE Questionnaire. Selain itu, penelitian ini juga bertujuan untuk mengetahui hubungan variabel terikat, baik secara simultan maupun parsial.

\section{B. Rumusan Masalah}

Berdasarkan latar belakang yang disampaikan di atas, maka rumusan masalah yang akan dibahas pada penelitian ini adalah "Apakah variabel Usefulness, Ease of Use, Ease of Learning berpengaruh pada variabel User Satisfaction secara signifikan?"

\section{Tujuan Penulisan}

Tujuan dari penelitian "Analisis Usability Menggunakan Metode USE Questionnaire Pada Website Ciputra Enterprise System" adalah untuk mengukur pengaruh variabel usefulness, ease of use, ease of learning terhadap user satisfaction.

\section{Ruang Lingkup}

Untuk mengarahkan penyusunan dan penelitian ini, peneliti membatasi ruang lingkup penelitian sebagai berikut:

1. Penelitian menggunakan website CES (Ciputra Enterprise System).

2. Responden yang digunakan dalam penelitian ini yaitu karyawan Ciputra atau pengguna website CES.

\section{LANDASAN TEORI}

\section{A. Usability}

Usability adalah tingkat dimana produk bisa digunakan oleh pengguna tertentu untuk mencapai tujuannya dengan lebih efektif, efisien, dan memuaskan dalam ruang lingkup penggunanya. ISO sudah mempunyai standar untuk usability seperti yang tercantum pada ISO 9241 - 11:2018 [1].

\section{B. Pengukuran Usability}

Pada umumnya, pengukuran ini dilakukan menggunakan kuesioner. Ada beberapa jenis kuesioner yang bisa digunakan untuk mengukur usability, yaitu:

1. Perceived Usefulness and Ease of Use (PUEU). Merupakan paket kuesioner yang terdiri dari 12 item instrumen.

2. WAMMI untuk mengukur website dan inventory.

3. Computer System Usability Questionnaire (CSUQ), yaitu kuesioner yang dirilis IBM dan terdiri dari 19 item instrumen.

4. Measurement of Usability of Multimedia Software (MUMMS)

5. USE (Usefulness, Ease of Use, Ease of Learning, Satisfaction), yang terdiri dari 30 item instrumen. [2]

\section{USE Questionnaire}

Kuesioner USE memiliki 30 pernyataan yang terbagi dari 4 parameter. Setiap pernyataan mewakili penilaian saat pengguna menggunakan aplikasi tersebut [3]. USE Questionnaire merupakan salah satu paket kuesioner yang diusulkan oleh Lund. Kuisioner ini dapat digunakan untuk mengukur usability karena mencakup tiga pengukuran menurut ISO 9241 yaitu efisiensi, efektifitas, dan kepuasan. Kuesioner ini mempunyai tiga variabel yang digunakan untuk mengukur sebuah kepuasan pengguna sistem (user satisfaction) yaitu variabel kebergunaan (Usefulness), kemudahan penggunaan (Ease of Use), kemudahan mempelajari (Ease of Learning), serta kepuasan pengguna (Satisfaction) [4].

Untuk melakukan penilaian dalam penelitian ini digunakan 5 poin model skala likert yang terdiri dari sangat setuju, setuju, netral, tidak setuju, dan sangat tidak setuju. Selanjutnya hasil yang diperoleh dari kuesioner akan di proses menggunakan metode statistik. Pada kuesioner terdapat pula kolom saran guna meningkatkan website menjadi lebih baik kedepannya. 


\section{User Satisfaction}

Kepuasan pengguna adalah suatu tanggapan yang diberikan responden berupa feedback setelah user menggunakan suatu sistem. Kepuasan user merupakan sebuah pencapaian dari sistem informasi. Dari kepuasan pengguna bisa diketahui bagaimana sikap dari pengguna tersebut terhadap sistem yang sudah dibuat [5].

\section{E. Variabel Penelitian}

Variabel penelitian adalah suatu nilai dari objek, individu yang mempunyai banyak macam tertentu [6]. Variabel peneitian digunakan sebagai wadah untuk mempelajari dan menarik kesimpulan dari penelitian yang dibuat. Ada dua jenis variabel yang digunakan pada penelitian ini yaitu variabel dependen dan independen. Variabel dependen adalah variabel yang mempengaruhi atau variabel terikat. Variabel independen adalah variabel bebas atau variabel yang dipengaruhi.

\section{METODE PENELITIAN}

\section{A. Metodologi Penelitian}

Metode pendekatan kuantitatif adalah metode yang penjelasannya secara deskriptif dan menggunakan analisis pendekatan dengan bantuan perhitungan statistik [7].

\section{B. Kerangka Konseptual}

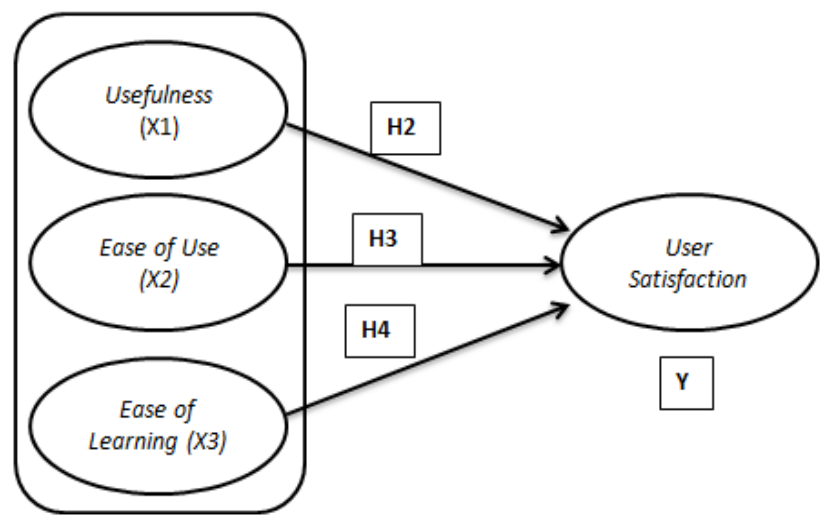

Gambar 1. Kerangka Konseptual USE Questionnaire [8]

C. Perumusan Hipotesis

Dari Gambar 1 model penelitian di atas, didapatkan hipotesis tersaji pada Tabel 1 sebagai berikut:

Tabel 1. Perumusan Hipotesis

Ho Tidak ada pengaruh yang signifikan di antara variabel bebas, yaitu variabel usefulness, ease of use, ease of learning terhadap variabel terikat yaitu satisfaction yang dilakukan secara simultan dan parsial

H1 Ada pengaruh yang signifikan di antara variabel bebas yaitu variabel usefulness, ease of use, dan ease of learning terhadap variabel terikat yaitu satisfaction yang dilakukan secara simultan dan parsial

H2 Ada pengaruh signifikan antara usefulness terhadap variabel terikat yaitu satisfaction

H3 Ada pengaruh signifikan antara variabel ease of use terhadap variabel terikat yaitu satisfaction

H4 Ada pengaruh yang signifikan antara ease of learning terhadap satisfaction

\section{Metode Pengumpulan Data}

Terdapat dua jenis sumber data dalam proses pengumpulan data yaitu data primer dan data sekunder. Data primer adalah data yang secara langsung diberikan kepada orang yang mengumpulkan data [9].

Skala likert merupakan skala yang mempunya empat atau lebih pilihan jawaban dan dicampur dengan sebuah nilai yang menjelaskan sikap dan perilaku responden [10]. Kuisioner dalam penelitian ini menggunakan skala likert dengan pilihan jawaban dan skor yaitu sangat tidak setuju (STS) memilki skor 1, Tidak setuju (TS) memiliki skor 2, Netral (N) memiliki skor 3, setuju (S) memiliki skor 4, dan sangat setuju (SS) memiliki skor 5 .

\section{E. Populasi}

Populasi adalah wilayah yang terdiri dari objek/subjek yang mempunyai kualitas dan karakter tertentu dan sudah ditetapkan oleh peneliti untuk dipelajari lalu kemudian ditarik kesimpulannya [11]. Dalam penelitian ini yang menjadi populasi adalah user dari karyawan Ciputra yang menggunakan Website CES dan pembagian kuesionernya dibantu oleh administrator dari website CES tersebut dengan jumlah populasi 500 orang.

\section{F. Sampel}

Penelitian ini menggunakan teknik pengambilan sampel probability sampling dengan teknik penentuan sampel random sampling (sampel random sederhana). Probability sampling berarti memberi kesempatan yang sama setiap populasi untuk dipilih menjadi sampel dan simple random sampling merupakan pengambilan sampel dari sebuah populasi secara acak tanpa melihat tingkatan (strata) dalam populasi. Hal ini dilakukan jika populasi yang dipilih sejenis atau homogen [12]. Sedangkan untuk penentuan sampel dari penelitian digunakan rumus Slovin:

$n=\frac{N}{1+N(e)^{2}}$

Dengan :

$n=$ ukuran sampel

$N=$ ukuran populasi

$e=$ taraf kesalahan pengambilan sampel $10 \%$

$n=\frac{500}{1+500(0,1)^{2}}=83,33$

Jumlah sampel dari penelitian ini adalah 83 orang responden. 
G. Instrumen Pernyataan

Instrumen dalam penelitian ini berupa kuesioner dari metode yang digunakan yaitu USE Questionnaire. Terdapat 4 variabel yaitu usefulness, ease of use, ease of learning, dan user satisfaction yang terdiri dari 30 pertanyaan tersaji pada Tabel 2 berikut ini.

Tabel 2. Kriteria Pengukuran USE Questionnaire Pernyataan Kuesioner

\section{Usefulness}

$\mathrm{X} 1.1 \quad$ It helps me be more effective.

$\mathrm{X} 1.2 \quad$ It helps me be more productive

$\mathrm{X} 1.3 \quad$ It is useful

$\mathrm{X} 1.4 \quad$ It gives me more control over the activities in my life.

$\mathrm{X} 1.5$ It makes the things I want to accomplish easier to get done.

$\mathrm{X} 1.6$ It saves me time when I use it.

$\mathrm{X} 1.7 \quad$ It meets my needs

$\mathrm{X} 1.8 \quad$ It does everything I would expect it to do.

Ease of Use

$\mathrm{X} 2.1 \quad$ It is easy to use.

$\mathrm{X} 2.2$ It is simple to use.

$\mathrm{X} 2.3$ It is user friendly.

$\mathrm{X} 2.4 \quad$ It requires the fewest steps possible to accomplish what I want to do with it.

$\mathrm{X} 2.5 \quad$ It is flexible.

$\mathrm{X} 2.6 \quad$ Using it is effortless.

$\mathrm{X} 2.7 \quad$ I can use it without written instructions.

X2.8 I don't notice any inconsistencies as I use it.

X2.9 Both occasional and regular users would like it.

X2.10 I can recover from mistakes quickly and easily.

$\mathrm{X} 2.11$ I can use it successfully every time.

\section{Ease of Learning}

X3.1 I learned to use it quickly.

X3.2 I easily remember how to use it.

X3.3 It is easy to learn to use it.

X3.4 I quickly became skillful with it.

\section{User Satisfaction}

Y4.1 I am satisfied with it.

Y4.2 I would recommend it to a friend.

Y4.3 It is fun to use.

Y4.4 It works the way I want it to work.

Y4.5 It is wonderful

Y4.6 I feel I need to have it.

Y4.7 It is pleasant to use.

\section{PEMBAHASAN}

Pada penelitian ini, peneliti ingin membuktikan apakah hipotesis yang ada mempunyai kontribusi positif atau negatif. Dari hipotesis yang sudah ditentukan, dicari hipotesis mana yang mempunyai pengaruh paling besar dalam mempengaruhi kepuasan pengguna (User Satisfaction).
Dari hasil pengambilan kuesioner maka didapatkan total sebanyak 105 responden yang berhasil disurvei yang didapatkan dari karyawan Ciputra yang sudah mulai menggunakan website CES (Ciputra Enterprise System). Berikut pada Tabel 3 disajikan data jumlah pengguna yang mengisi kuisioner dari sejumlah pengguna website CES pada berbagai proyek.

Tabel 3. Responden Berdasarkan Nama Proyek

$$
\text { Nama Proyek }
$$

Jumlah Persentase Responden

\begin{tabular}{lrr}
\hline Citraland Surabaya & 27 & $25,7 \%$ \\
\hline Citraland Manado & 17 & $16,2 \%$ \\
\hline Citraland Palu & 4 & $3,8 \%$ \\
\hline Citraland Kendari & 5 & $4,8 \%$ \\
\hline Citrasun Garden Semarang & 5 & $4,8 \%$ \\
\hline Citra Grand Semarang & 5 & $4,8 \%$ \\
\hline The Taman Dayu Pasuruan & 6 & $5,7 \%$ \\
\hline Citraland Tallasa City & 3 & $2,9 \%$ \\
\hline Ciputra World Surabaya & 1 & $1 \%$ \\
\hline Citraland Vittorio Surabaya & 1 & $1 \%$ \\
\hline Citraland Surabaya-Utara & 7 & $6,7 \%$ \\
\hline Citraland Surabaya The & 6 & $5,7 \%$ \\
Greenlake & & \\
\hline Citraland Driyorejo & 3 & $2,9 \%$ \\
\hline Citra Harmoni Sidoarjo & 6 & $5,7 \%$ \\
\hline Citra Garden Sidoarjo & 4 & $3.8 \%$ \\
\hline Barza City Yogyakarta & 3 & $2,9 \%$ \\
\hline Citra Grand Mutiara Yogyakarta & 2 & $1,9 \%$ \\
\hline Total & 105 & $100 \%$ \\
\hline
\end{tabular}

\section{Uji Validitas}

Pengujian dilakukan dengan metode analisis Bivariate Pearson yaitu mengkorelasikan skor item terhadap skor total dengan menggunakan SPSS. Item pertanyaan dinyatakan valid apabila memiliki nilai signifikansi $\leq 0,05$. Berikut pada Tabel 4 merupakan hasil uji validitas yang dilakukan dalam penelitian [13].

Tabel 4. Hasil Uji Validitas

\begin{tabular}{lcc}
\hline Indikator & $\begin{array}{c}\text { Pearson } \\
\text { Correlation }\end{array}$ & $\begin{array}{c}\text { Sig. (2- } \\
\text { Tailed) }\end{array}$ \\
\hline Usefulness & & \\
\hline X1.1 & $0,744^{* *}$ & 0,000 \\
\hline X1.2 & $0,848^{* *}$ & 0,000 \\
\hline X1.3 & $0,822^{* *}$ & 0,000 \\
\hline X1.4 & $0,778^{* *}$ & 0,000 \\
\hline X1.5 & $0,816^{* *}$ & 0,000 \\
\hline X1.6 & $0,815^{* *}$ & 0,000 \\
\hline X1.7 & $0,855^{* *}$ & 0,000 \\
\hline X1.8 & $0,776^{* *}$ & 0,000 \\
\hline Ease of Use & & \\
\hline X2.1 & $0,845^{* *}$ & 0,000 \\
\hline X2.2 & $0,834^{* *}$ & 0,000 \\
\hline X2.3 & $0,796^{* *}$ & 0,000 \\
\hline X2.4 & $0,815^{* *}$ & 0,000 \\
\hline
\end{tabular}




\begin{tabular}{lcc}
\hline X2.5 & $0,781^{* *}$ & 0,000 \\
\hline X2.6 & $0,860^{* *}$ & 0,000 \\
\hline X2.7 & $0,722^{* *}$ & 0,000 \\
\hline X2.8 & $0,804^{* *}$ & 0,000 \\
\hline X2.9 & $0,743^{* *}$ & 0,000 \\
\hline X2.10 & $0,702^{* *}$ & 0,000 \\
\hline X2.11 & $0,762^{* *}$ & 0,000 \\
\hline Ease of Learning & \\
\hline X3.1 & $0,881^{* *}$ & 0,000 \\
\hline X3.2 & $0,842^{* *}$ & 0,000 \\
\hline X3.3 & $0,916^{* *}$ & 0,000 \\
\hline X3.4 & $0,833^{* *}$ & 0,000 \\
\hline User Satisfaction & \\
\hline Y4.1 & $0,898^{* *}$ & 0,000 \\
\hline Y4.2 & $0,896^{* *}$ & 0,000 \\
\hline Y4.3 & $0,917^{* *}$ & 0,000 \\
\hline Y4.4 & $0,861^{* *}$ & 0,000 \\
\hline Y4.5 & $0,881^{* *}$ & 0,000 \\
\hline Y4.6 & $0,886^{* *}$ & 0,000 \\
\hline Y4.7 & $0,857^{* *}$ & 0,000 \\
\hline
\end{tabular}

* Di hitung berdasar korelasi antara masing-masing indikator terhadap total indikator setiap variabel

** Korelasi signifikan pada level 0,01 (2-Tailed)

Pada Tabel 4 di atas kita dapat mengetahui indikator pada instrument sig.(2 tailed) memiliki nilai signifikansi $\leq 0,05$ hal tersebut menunjukan indikator instrumen valid.

\section{Uji Reliabilitas}

Uji reliabilitas digunakan untuk melihat konsistensi suatu instrumen sehingga instrumen tersebut dapat diandalkan dalam mengukur variabel penelitian. Selain itu, perhitungan reliabilitas juga dilakukan untuk mengetahui hasil dari jawaban yang diberikan oleh responden apakah dapat digunakan untuk tahap pengolahan berikutnya atau tidak. Hasil uji reliabilitas dapat dilihat dari koefisien Cronbach's Alpha. Instrumen dapat dinyatakan reliabel apabila memiliki nilai Cronbach Alpha $\geq 0,7$. Berikut merupakan uji reliabilitas yang dilakukan dalam penelitian.

\begin{tabular}{|rr}
\multicolumn{2}{|c|}{ Tabel 5. Uji Reliabilitas } \\
\hline Cronbach's Alpha & N of Items \\
\hline 0,935 & 4 \\
\hline
\end{tabular}

Pada tabel 5 menampilkan hasil nilai reliabilitas pada kolom "Cronbach Alpha" dengan nilai Cronbach Alpha $\geq 0,7$ maka dapat disimpulkan bahwa indikator instrumen yang digunakan reliabel dan pengolahan data lebih lanjut dapat dilakukan.

\section{Uji Normalitas}

Pengujian dilakukan untuk melihat sebaran nilai dari sebuah data. Dilakukan menggunakan uji Kolmogorov Smirnov yaitu dengan membandingkan distribusi data yang akan diuji normalitasnya dengan distribusi normal baku. Apabila nilai signifikansi $\geq 0,05$ maka tidak terjadi perbedaan yang signifikan antara data yang diuji dengan data normal baku [14].

Tabel 6. Uji Normalitas One-Sample Kolmogorov-Smirnov Test Asymp. Sig. (2 tailed) 0,093

Pada Tabel 6 nilai signifikansi "Asymp. Sig. (2 tailed)" $\geq 0,05$ maka dapat dikatakan memenuhi asumsi normalitas. Data terdistribusi secara normal sesuai dengan dasar pengambilan keputusan dalam uji normalitas KolmogorovSmirnov.

\section{Uji Multikolinearitas}

Pengujian dilakukan untuk melihat apakah pada model regresi linier berganda ditemukan korelasi antara variabel bebas. Model regresi yang baik adalah ketika tidak terdapat hubungan kuat antara variabel bebas. Dasar pengambilan keputusan yaitu dengan melihat nilai Tolerance dan VIF (Variance Inflation Factor). Apabila nilai Tolerance $\geq 0,1$ dan nilai VIF $\leq 10,00$ maka tidak terjadi gejala multikolonieritas dalam model regresi.

Tabel 7. Uji Multikolonieritas

\begin{tabular}{|lrc|}
\hline \multicolumn{3}{|c}{ Collinearity Statistics } \\
Model & Tolerance & VIF \\
\hline Usefulness (X1) & 0,301 & 3,317 \\
\hline Ease of Use (X2) & 0,205 & 4,884 \\
\hline Ease of Learning (X3) & 0,377 & 2,655 \\
\hline
\end{tabular}

Pada Tabel 7, bagian "collinearity statistics" diketahui nilai Tolerance $\geq 0,1$ dan VIF $\leq 10$ dari tiga variabel bebas maka tidak terjadi multikolonieritas.

\section{Uji Heteroskedastisitas}

Pengujian dilakukan untuk melihat apakah model regresi terjadi ketidaksamaan Variance (variasi) dari nilai residual satu ke pengamatan yang lain. Jika residual pada satu pengamatan ke pengamatan lain bersifat berbeda maka disebut dengan heteroskedastisitas. Model regresi yang baik tidak terjadi heteroskedastisitas. Apabila variabel independen tidak mempengaruhi Absolute Residual atau Abs_RES maka tidak ada indikasi heteroskedastisitas yaitu dengan memiliki nilai signifikansi $\geq 0,05$.

Tabel 8. Uji Heteroskedastisitas

\begin{tabular}{lc}
\hline \multicolumn{1}{|c}{ Model } & Sig. \\
\hline Usefulness (X1) & 0,152 \\
\hline Ease of Use (X2) & 0,081 \\
\hline Ease of Learning (X3) & 0,645 \\
\hline
\end{tabular}

Untuk melihat output pada Tabel 8 dengan variabel $A b s \_R E S$ yaitu berperan sebagai variabel terikat atau dependen. Tiap variabel bebas memiliki nilai signifikansi $\geq 0,05$ yaitu tidak memiliki gejala heteroskedastisitas dalam model regresi. 


\section{Uji Autokorelasi}

Uji autokorelasi merupakan sebuah analisis statistik digunakan untuk melihat terjadinya error dalam korelasi antar variabel. Autokorelasi muncul karena pengamatan yang berurutan sepanjang waktu berkaitan satu sama lain. Model regresi yang baik tidak terjadi autokorelasi dengan melakukan uji Durbin Watson yaitu sebagai dasar pengambilan keputusan:

a. d > 4-dL; maka terjadi autokorelasi negatif

b. $\mathrm{dU}<\mathrm{d}<4-\mathrm{dU}$; maka tidak terjadi autokorelasi

c. $\mathrm{dL}<\mathrm{d}<\mathrm{dU}$ atau $4-\mathrm{dU}<\mathrm{d}<4-\mathrm{dL}$; maka pengujian tidak meyakinkan

\begin{tabular}{|rr}
\multicolumn{2}{|c}{ Tabel 9. Uji Autokorelasi } \\
\hline Model & Durbin Watson \\
\hline 1 & 1,850 \\
\hline
\end{tabular}

Berdasarkan output Tabel 9, diketahui nilai Durbin Watson (DW) yaitu 1,850. Nilai tabel dU dengan jumlah (N) 105 sesuai dengan tabel Durbin Watson yaitu 1,737 (dU) dan 2,263 (4-dU) . Nilai Durbin Watson terletak di antara nilai $d U$ dan $4-d U$. Dengan ini tidak terjadi autokorelasi pada seluruh variabel.

\section{Uji Liniearitas}

Pengujian ini digunakan untuk mengetahui apakah diantara variabel independen (x) dan dependen (y) terdapat korelasi. Dasar pengambilan keputusan yaitu jika nilai Signifikansi Linierity $\leq 0,05$ maka dapat disimpulkan terdapat hubungan linier antara $\mathrm{x}$ dan $\mathrm{y}$.

\section{Tabel 10. Uji Linieritas}

\begin{tabular}{lrl}
\multicolumn{1}{c}{ Variabel } & $\begin{array}{c}\text { Nilai } \\
\text { Signifikansi }\end{array}$ & Keterangan \\
\hline Usefulness $(\mathrm{X} 1)$ & $\mathbf{0 , 0 0 0}$ & Linier \\
\hline Ease of Use $(\mathrm{X} 2)$ & $\mathbf{0 , 0 0 0}$ & Linier \\
\hline Ease of Learning $(\mathrm{X} 3)$ & $\mathbf{0 , 0 0 0}$ & Linear \\
\hline
\end{tabular}

Berdasarkan nilai signifikansi Tabel 10, menunjukan bahwa tiga variabel memiliki hubungan yang linier dengan nilai signifikansi linearity 0,000 yang lebih kecil dari 0,05 sehingga variabel Usefulness, Ease of Use, Ease of Learning mempunyai hubungan linier secara signifikan.

\section{Analisis Regresi Linier Berganda}

Analisis regresi linier berganda digunakan untuk melihat ada tidaknya pengaruh dari dua atau lebih variabel independen dari USE Questionnaire yaitu Usefulness, Ease of Use, dan Ease of Learning terhadap variabel dependen kepuasan pengguna (User Satisfaction).

Tabel 11. Uji Regresi Linier Berganda

\begin{tabular}{lr}
\hline \multicolumn{1}{c}{ Model } & B (Koefisien Regresi) \\
\hline Constant & $-0,099$ \\
\hline Usefulness $(\mathrm{X} 1)$ & 0,259 \\
\hline Ease of Use (X2) & 0,367 \\
\hline Ease of Learning (X3) & 0,390 \\
\hline
\end{tabular}

Pada coefficients Tabel 11 menampilkan informasi model persamaan regresi sebagai berikut :

$Y=-0,099+0,259 \mathrm{X} 1+0,367 \mathrm{X} 2+0,390 \mathrm{X} 3$

Interpretasi dari persamaan diatas sebagai berikut :

1) Koefisien regresi dari variabel X1 (Usefulness) mempunyai nilai sebesar 0,259 yaitu memiliki arah positif dalam kepuasan pengguna (User Satisfaction).

2) Koefisien regresi dari variabel $\mathrm{X} 2$ (Ease of Use) mempunyai nilai sebesar 0,367 yaitu memiliki arah positif dalam kepuasan pengguna (User Satisfaction).

3) Koefisien regresi dari variabel X3 (Ease of Learning) mempunyai nilai sebesar 0,390 yaitu memiliki arah positif dalam kepuasan pengguna (User Satisfaction).

\section{Uji Signifikansi Parsial (Uji T)}

Uji signifikansi parsial (Uji T) ini dikenal dengan uji parsial, berfungsi untuk menguji masing-masing variabel bebas secara parsial. Dilakukan dengan membandingkan nilai dari $t$ hitung dengan $t$ tabel. Dasar pengambilan keputusan yaitu apabila nilai signifikansi lebih kecil dari 0,05 dan nilai $t$ hitung lebih besar dari nilai $t$ tabel.

\begin{tabular}{lcc}
\multicolumn{4}{c}{ Tabel 12. Uji T } \\
\hline \multicolumn{1}{c}{ Model } & T & Sig. \\
\hline Usefulness (X1) & $-0,408$ & 0,684 \\
\hline Ease of Use (X2) & 3,006 & 0,003 \\
\hline Ease of Learning (X3) & 3,569 & 0,001 \\
\hline Usefulness (X1) & 4,216 & 0,000 \\
\hline
\end{tabular}

a. Variabel usefulness

Berdasarkan Tabel 12 di atas diketahui nilai signifikansi variabel Usefulness nilai X1 0,003 lebih kecil dari 0,05 untuk nilai t hitung 3,006 lebih besar dari t tabel adalah 1,982. Dapat disimpulkan variabel Usefulness memiliki pengaruh signifikan terhadap kepuasan pengguna, maka hipotesis 2 diterima.

\section{b. Variabel Ease of Use}

Berdasarkan Tabel 12 di atas diketahui nilai signifikansi variabel Ease of Use nilai X2 0,001 lebih kecil dari 0,05 untuk nilai t hitung 3,569 lebih besar dari t tabel adalah 1,982. Dapat disimpulkan variabel Ease of Use memiliki pengaruh signifikan terhadap kepuasan pengguna, maka hipotesis 3 diterima.

\section{c. Variabel Ease of learning}

Berdasarkan Tabel 12 di atas diketahui nilai signifikansi variabel Ease of Learning nilai X3 0,000 lebih kecil dari 0,05 untuk nilai thitung 4,216 lebih besar dari t tabel adalah 1,982. Dapat disimpulkan variabel Ease of Learning memiliki pengaruh signifikan terhadap kepuasan pengguna, maka hipotesis 4 diterima.

\section{Uji Signifikansi Simultan (Uji F)}

Uji signifikansi simultan (Uji F) digunakan untuk melihat pengaruh semua variabel bebas secara bersama-sama terhadap variabel terikat. Melihat nilai $f$ hitung lebih besar 
daripada $f$ tabel. Jika nilai signifikansi $\leq 0,05$ maka variabel bebas mempengaruhi variabel terikat secara bersama-sama.

\begin{tabular}{rcr}
\multicolumn{3}{c}{ Tabel 13. Uji F } \\
\hline \multicolumn{3}{c}{ Anova } \\
Model & F & F Tabel \\
\hline 1 & 115,743 & 2,30 \\
\hline
\end{tabular}

Pada Tabel 13 didapatkan nilai $f$ hitung 115,743 lebih besar dari nilai $f$ tabel yaitu 2,30. Nilai signifikansi 0,00 lebih kecil dari 0,05 sesuai dengan dasar pengambilan keputusan, sehingga dapat disimpulkan variabel Usefulness, Ease of Use, Ease of Learning secara stimultan dan memiliki arah positif dalam mempengaruhi kepuasan pengguna website CES Ciputra

\section{Uji Koefisien Determinasi (R2 Square)}

Uji ini dapat digunakan untuk melihat kontribusi variabel bebas terhadap variabel terikat. Tujuan koefisien determinasi untuk mengukur seberapa jauh kemampuan model menerangkan variasi variabel bebas. Nilai koefisien determinasi antara nol sampai satu. Jika nilai R2 kecil maka kemampuan variabel independen dalam menjelaskan variabel dependen sangat terbatas atau tidak mempengaruhi.

\section{Tabel 14. Uji Koefisien Determinansi

\begin{tabular}{cc} 
Model & R Square \\
\hline 1 & 0,768 \\
\hline
\end{tabular}

Pada Tabel 14 output Model Summary diketahui memiliki nilai koefisien determinasi yaitu 0,768 atau sama dengan 76,8\%. Angka tersebut memiliki arti variabel Usefulness, Ease of Use, Ease of Learning berpengaruh terhadap kepuasan pengguna. Sedangkan sisanya yaitu 23,2\% dipengaruhi dari variabel di luar model regresi ini. Besarnya variabel di luar model regresi biasanya disebut error. Nilai koefisien determinasi adalah antara 0-1. jika nilai koefisien determinasi semakin mendekati 1 berarti memiliki pengaruh yang semakin kuat.

\section{KESIMPULAN}

Hasil penelitian pada variabel Usefulness memiliki pengaruh secara parsial, secara signifikan dan juga memiliki arah positif pada User Satisfaction dengan melihat nilai yang dihasilkan dari variabel Usefulness pada Uji $t$ yaitu 3,006. Hal tersebut memberikan fakta bahwa dimensi Usefulness pada penggunaan website CES ditingkatkan, maka dapat mempengaruhi meningkatnya User Satisfaction. Pada persamaan koefisien regresi mempunyai nilai 0,259 yang membuktikan arah positif. Jika variabel Usefulness semakin baik maka semakin baik juga User Satisfaction dalam website CES.

Hasil penelitian pada variabel Ease of Use memiliki pengaruh secara parsial, secara signifikan dan juga memiliki arah positif pada User Satisfaction dengan melihat nilai yang dihasilkan dari variabel Ease of Use pada Uji t yaitu 3,569.
Hal tersebut memberikan fakta bahwa saat dimensi Ease of Use atau kemudahan penggunaan pada website CES ditingkatkan dapat mempengaruhi meningkatnya User Satisfaction. Pada persamaan koefisien regresi mempunyai nilai 0,367 membuktikan memiliki arah positif yang berarti jika variabel Ease of Use semakin baik maka semakin baik juga User Satisfaction dalam website CES.

Hasil penelitian pada variabel Ease of Learning memiliki pengaruh secara parsial dan signifikan terhadap User Satisfaction. memiliki nilai pada uji $t 4,216$ hal ini membuat variabel Ease of Learning memiliki pengaruh secara parsial paling besar dibanding variabel yang lain. Variabel Ease of Learning membahas mengenai bagaimana kemudahan belajar sehingga pengguna mudah dalam menggunakannya. Dalam hal ini perusahaan dapat memberikan training tambahan untuk karyawan atau memberikan buku panduan manual untuk dipelajari. Jika hal tersebut ditingkatkan maka kepuasan pengguna juga akan semakin bertambah. Koefisien regresi variabel ini memiliki nilai 0,390 juga memiliki arah positif yang paling besar juga dibanding variabel lainnya, artinya jika variabel Ease of Learning semakin baik maka semakin baik juga pada User Satisfaction.

Hasil dari seluruh variabel independen yaitu Usefulness, Ease of Use, dan Ease of Learning secara bersama-sama memiliki pengaruh secara stimultan pada website CES. Nilai pada $f$ hitung 115,743 lebih besar daripada $f$ tabel yaitu 2,30 dengan siginifikansi 0,00 . Variabel independen dari USE Questionnaire memiliki nilai koefisien determinasi yaitu 0,775 artinya seluruh dimensi pada variabel independen memiliki pengaruh pada User Satisfaction sebesar 77,5\%.

Setelah melakukan beberapa tahap penelitian dan proses analisis terdapat persamaan regresi sebagai berikut:

$\mathrm{Y}=0,259 X 1+0,367 X 2+0,390 X 3$

Dari persamaan regresi di atas didapatkan koefisien dari variabel Ease of Learning mempunyai pengaruh paling besar terhadap User Satisfaction website CES, maka diharapkan variabel ini berdampak besar dalam peningkatan User Satisfaction pada penggunaan website CES

Berdasarkan penjabaran di atas, peneliti sudah menjawab rumusan masalah "Apakah variabel Usefulness, Ease of Use, Ease of Learning berpengaruh pada variabel User Satisfaction secara signifikan?" yaitu semua variabel berpengaruh secara signifikan terhadap user satisfaction.

\section{UCAPAN TERIMA KASIH}

Penulis ingin menyampaikan rasa terima kasih sebesarbesarnya kepada:

1. Tuhan Yang Maha Esa atas rahmat, berkat, dan kasih karunia-Nya sehinga penulis diberikan kelancaran dan pencerahan setiap langkah dalam penulisan.

2. Dosen pembimbing yang senantiasa meluangkan waktu dan pemikirannya di sela-sela kesibukan beliau untuk menuntun, membimbing, mengarahkan, memberi motivasi, serta saran.

3. Orang tua dan saudara kandung dari penulis yang selalu memberi semangat, dukungan, doa, dan motivasi. 


\section{REFERENSI}

[1] ISO. (2018). ISO 9241-11:2018. Diakses dari https://www.iso.org/Obp/Ui/\#Iso:Std:Iso:9241:11:Ed2:V1:En pada tanggal 19 November 2019.

[2] Amelia, L., \& Novita, D. (2019). Analisis Usability Aplikasi Pengisian KRS Online STMIK XYZ Palembang Menggunakan Use Questionnaire. Jurnal Informasi Dan Komputer, Vol. 7(1), pp. 17-28.

[3] Hadi, K.R., Az-Zahra, H.M. \& Fanani, L. (2018). Analisis Dan Perbaikan Usability Aplikasi Mobile Kai Access Dengan Metode Usability Testing Dan Use Questionnaire. Jurnal Pengembangan Teknologi Informasi Dan Ilmu Komputer, Vol. 2(9), pp. 27422750.

[4] Marthasari, G.I. \& Hayatin, N. (2017). Analisis Usability Terhadap Sistem Lective Gegulang Berbasis USE Questionnaire. Prosiding Seminar Teknologi dan Rekayasa (SENTRA).

[5] Machmud, R. (2018). Kepuasan Penggunaan Sistem Informasi (Studi Kasus Pada T3-Online). Gorontalo: Ideas Publishing.

[6] Ridha, N. (2017). Proses Penelitian, Masalah, Variabel Dan Paradigma Penelitian. Jurnal Hikmah, Vol. 14(1).

[7] Herdana, A. (2015). Analisis Pengaruh Kesadaran Merek (Brand Awareness) Pada Produk Asuransi Jiwa Prudential Life Assurance (Studi Pada Pru Passion Agency Jakarta). Jurnal Riset Bisnis Dan Manajemen, Vol. 3.

[8] Kusuma, W.A., \& Noviasari, V. (2016). Analisis Usability Dalam User Experience Pada Sistem KRS Online UMM Menggunakan USE Questionnaire. Jurnal
Nasional Teknik Elektro dan Teknologi Informasi (JNTETI), Vol. 5(4), pp. 294-301.

[9] Viola, M., Ekawati, R.K. \& Wijaya, T. (2017). Analisis dan Perancangan Sistem Informasi Akuntansi Penjualan dan Persediaan Pada PT XYZ. Jurnal Terapan Teknologi Informasi (JUTEI), Vol. 1(2), pp. 155-164.

[10] Maryuliana, Subroto, I.M.I. \& Haviana, S.F.C. (2016). Sistem Informasi Angket Pengukuran Skala Kebutuhan Materi Pembelajaran Tambahan Sebagai Pendukung Pengambilan Keputusan di Sekolah Menengah Atas Menggunakan Skala Likert. Jurnal Transistor Elektro dan Informatika, Vol. 1(1), pp. 1-12.

[11]Dewi, M.A.C. (2019). Pengaruh Persepsi Kegunaan, Persepsi Kemudahan, Keamanan Dan Kerahasiaan, Tingkat Kesiapan Teknologi Informasi Dan Kepuasan Pengguna Wajib Pajak Terhadap Intensitas Perilaku Wajib Pajak Dalam Penggunaan E-Filling. Jurnal Sains, Akuntansi Dan Manajemen (JSAM), Vol. 1(3), pp. 317367

[12]Binus University. (2017). Probability Sampling Vs. Non-Probability Sampling. Diakses dari: http://scdc.binus.ac.id/Himsisfo/2017/03/ProbabilitySampling-Vs-Non-Probability-Sampling/ pada tanggal 22 November 2019

[13] Tanamal, R. (2017). Analisis Faktor Yang Paling Berpengaruh Pada Keinginan Menggunakan Applikasi Grab Di Kota Surabaya. Jurnal Terapan Teknologi Informasi (JUTEI), Vol. 1(2), pp. 121-130.

[14] Ghozali. (2016). Aplikasi Analisis Multivariate Dengan Program IBM SPSS 23. Semarang: Badan Penerbit Universitas Diponegoro. 